\title{
Daya Saing Komoditas Padi Sawah di Kecamatan Biboki Moenleu Kabupaten Timor Tengah Utara Provinsi Nusa Tenggara Timur
}

Umbu Joka $^{\mathrm{a}}$, Yohanes Pebrian Vianney Mambur ${ }^{\mathrm{b}}$

a Fakultas Pertanian, Universitas Timor, Kefamenanu, TTU - NTT, Indonesia.Email: umbujoka@ unimor.ac.id

${ }^{b}$ Fakultas Pertanian, Universitas Timor, Kefamenanu, TTU - NTT, Indonesia. Email: vianneymambur@ gmail.com

\section{Article Info}

\section{Article history:}

Received 18 Agustus 2020

Received in revised form 5 September 2020 Accepted 20 September 2020

DOI:

https://doi.org/10.32938/ag.v5i4.1176

Keywords:

Daya Saing

Komparatif

Kompetetif

Padi

\section{Abstrak}

Penelitian ini bertujuan untuk menganalisis daya saing ( keunggulan komparatif dan keunggulan kompetitif) serta menganalisa dampak kebijakan pemerintah pada harga input (subsidi pupuk) dan output (harga dasar gabah) terhadap pendapatan usahatani padi sawah di Kecamatan Biboki Moenleu, Kabupaten Timor Tengah Utara. Penelitian ini dilaksanakan dari bulan Juli s/d Agustus tahun 2020. Penentuan sampel mengunakan teknik simple random sampling yaitu secara acak berjumlah 100 petani. Jenis data yang digunakan yaitu data primer dan data sekunder. Metode analisis data yang digunakan yaitu metode deskriptif kualitatif dan Policy Analisys Matrix (PAM). Hasil penelitian : 1) Usahatani padi sawah di Kecamatan Biboki Moenleu, Kabupaten Timor Tengah Utara memilki keunggulan kompetitif nilai Private Cost Ratio (PCR) sebesar 0,19 dan keungoulan komparatif nilai Domestic Resource Cost Ratio (DRCR) sebesar 0,13 sehingga usahatani padi sawah layak untuk diteruskan. 2). Kebijakan pemerintah pada harga input-output pada usahatani padi sawah di Kecamatan Biboki Moenleu, Kabupaten Timor Tengah Utara berdampak nyata terhadap pendapatan petani padi sawah pada harga privat dengan nilai Nominal Protection Coefficient on Tradable Output (NPCO) sebesar 1,13 dan nilai Subsidy Ratio of Producer (SRP) sebesar 0,05 .

\section{Pendahuluan}

Padi merupakan salah satu komoditi favorit yang sering mengundang polemik karena memiliki posisi yang startegis baik dari segi ekonomi, lingkungan hidup, sosial maupun politik. Padi menjadi komoditi yang menyita perhatian publik termasuk pemerintah, beragam polemik dimulai dari budidaya yang akan sering diperhadapkan dengan isu alih fungsi lahan, perlindungan terhadap petani sebagai produsen melalui subsidi pupuk, pemasaran komoditas, penguasaan lahan yang masih kecil $(0.3 \mathrm{Ha})$ sehingga sebagian petani tergolong petani gurem, isu lingkungan, belum lagi isu-isu politik yang gampang menyeret berbagai deretan problematika yang akan berujung pada inefisiens produksi dan juga berpengaruh pada daya saing produk akhir berupa beras. Roidah (2015) mengemukakan padi difavoritkan karena produk olahannya berupa beras memiliki harga yang tinggi, mudah dibudidayakan, dan gampang dipasarkan, ini menambah pendapatan para petani (Joka et al.,2019), sehingga memotivasi petani untuk meningkatkan produksi dengan harapan akan memperoleh hasil penjualan yang tinggi. Namun secara aktual pada saat panen tiba, hasil melimpah tetap harga menjadi turun, dan terlebih lagi jika hasi produksi yang diharapkan jauh dari perkiraan, yaitu pembeli sangat rendah, produksi minim, biaya untuk kegiatan produksi, mulai dari pengadaan pupuk, pengolahan, pestisida dan biaya lainnya yang tidak terduga.

Kecamatan Biboki Moenleu merupakan salah satu kecamatan yang terletak di Kabupaten Timor Tengah Utara yang dimana sebagian besar penduduknya bermatapencaharian sebagai petani yang mengusahakan padi sawah. Kecamatan Biboki Moenleu selama ini terus menerus mengalami penurunan dalam mengusahakan usahatani padi sawah, faktor penyebab utama antara lain keadaan iklim khususnya curah hujan di tahun 2015 dan 2016 yang tidak menentu mengakibatkan pengaruh produksi usahatani padi sawah secara keseluruhan. Berdasarkan data produksi yang diperoleh dari Kecamatan Biboki Moeneleu yang meliputi tiga Desa yaitu: Desa Oepuah Induk, Desa Oepuah Utara, Desa Oepuah Selatan mengalami fluktuasi dihitung dari tahun 2015 2017 dapat dilihat pada Gambar 1

Keunggulan kompetitif diartikan sebagai kemampuan suatu komoditi bersaing di pasar internasional secara finansial, sedangkan keunggulan komparatif yaitu kemampuan suatu komoditi bersaing di pasar internasional secara ekonomi/sosial. Keunggulan kompetitif disebut juga PCR (Private Cos Ratio) dan harus bernilai < 1 agar memiliki keunggulan kompetitif, sedangkan keunggulan komparatif desebut juga DRCR (Domestic Cost Ratio) dan juga harus bernilai < 1 agar memiliki keunggulan komparatif (Pearson, 2003 Haryono, et al., 2011; Rum, 2010). Semakin rendah/kecil nilai kedua keunggulan tersebut maka usahatani tersebut semakin tinggi daya saingnya atau semakin efisien.

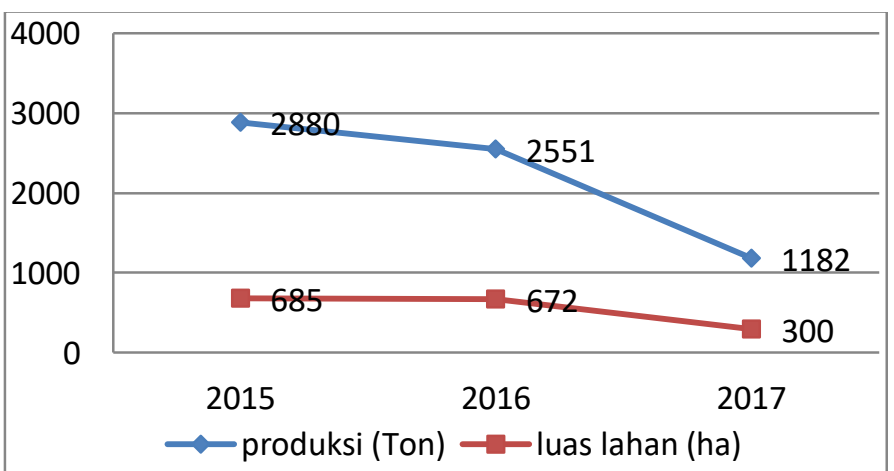

Gambar 1. Data produksi dan luas tanam Kecamatan Biboki Moenleu tahun 2015-2017. Sumber : BPS Kabupaten TTU,2018
Berdasarkan uraian latar belakang di atas, maka permasalahan yang diangkat dalam penelitian ini adalah bagaimana daya saing (keunggulan komparatif dan keunggulan kompetitif) serta bagaimana dampak kebijakan pemerintah pada harga input (subsidi pupuk) dan output (harga dasar gabah) terhadap pendapatan usahatani padi sawah di Kecamatan Biboki Moenleu, Kabupaten Timor Tengah Utara.

Tujuan penelitian ini adalah untuk menganalisis daya saing (keunggulan komparatif dan keunggulan kompetitif) komoditas serta menganalisis dampak kebijakan pemerintah pada harga input (subsidi pupuk) dan output (harga dasar gabah) terhadap pendapatan usahatani padi sawah di Kecamatan Biboki Moenleu, Kabupaten Timor Tengah Utara.

\section{Metode}

Penelitian ini dilasanakan dari bulan Juli 2020 sampai dengan Agustus 2020. Penelitian ini merupakan penelitian survei dan telah dilaksanakan di Kecamatan Biboki Moenleu yang meliputi tiga desa diantarnya: yang dipilih dengan pertimbangan jumlah kepala keluarga tani paling banyak yaitu Desa Oepuah Induk sebanyak 460 petani, Desa Oepuah Utara sebanyak 433 petani, Desa Oepuah Selatan sebanyak 234 petani, sehingga total petani adalah sebanyak 1.127 petani. Penetapan jumlah sampel penelitian dilakukan dengan caramenggunakan rumus Slovin (Umar, 2000) yaitu:

$$
\mathrm{n}=\frac{N}{1+N(e)^{2}}
$$

sehingga responden berjumlah 100 petani. Jenis data yang digunakan yaitu data primer dan data sekunder. Metode analisis data yang digunakan yaitu metode deskriptif kualitatif dan analisis pendapatan.

\subsection{Teknik Pengumpulan Data}

Data yang dikumpulkan dalam penelitian ini terdiri dari data primer dan data sekunder. Data primer diperoleh dari wawancara langsung dengan petani melalui survei dan daftar kuesioner yang telah dipersiapkan terlebih dahulu. Sedangkan data sekunder diperoleh dari literatur literatur yang relavan seperti buku, jurnal, internet, dan diperoleh dari instansi atau lembaga terkait dengan substansi penelitian, seperti Badan Pusat Statistik (BPS) Provinsi NTT, Badan Pusat Statistik (BPS) Kabupaten Timor Tengah Utara, Dinas Pertanian Kabupaten TTU, Kantor Desa Oepuah, Kantor Desa Oepuah Utara, Kantor Desa Oepuah Selatan dan instansi lainnya yang berhubungan dengan penelitian ini

\subsection{Metode Analisis Data}

Untuk tujuan menganalisis daya saing (keunggulan komparatif dan keunggulan kompetitif) usahatani komoditi padi sawah di Kecamatan Biboki Monleu dan menganalisis dampak kebijakan pemerintah pada harga input (subsidi pupuk)-output (harga dasar gabah) terhadap usahatani padi sawah di di Kecamatan Biboki Monleu, menggunakan Policy Analysis Matrix (PAM), dapat dilihat pada Tabel 1

Indikator Analisis Matrix

a. Analisis Keuntungan

Private Provitability (Keuntungan Privat) D $=\mathrm{A}-(\mathrm{B}+\mathrm{C})$

Social Provitability (Keuntungan Sosial) H $\quad$ E $-(\mathrm{F}+\mathrm{G})$

b. Efisiensi Finansial dan Efisiensi Ekonom Private Cost Ratio (PCR)

Domestic Resource Cost Ratio (DRCR)

$\mathrm{PCR}=\mathrm{C} /(\mathrm{A}-\mathrm{B})$

c. Dampak Kebijakan Pemerintah

Kebijakan Output, terdiri dari :
- Transfer Output
- Nominal Protection Coefficient on Output

$\mathrm{DRCR}=\mathrm{G} /(\mathrm{E}-\mathrm{F})$ 
Kebijakan Input, terdiri dari :

- Transfer Input

- Nominal Protection Coefficient on Input

- Transfer Faktor

Kebijakan Input-Output, terdiri dari :

- Efective Protection Coefficient

- Net Transfer

- Profitability Coeffisien

- Subsidy Ratio to Producer

$\begin{array}{ll}\mathrm{J} & =\mathrm{B}-\mathrm{F} \\ \mathrm{NPCI} & =\mathrm{B} / \mathrm{F} \\ \mathrm{K} & =\mathrm{C}-\mathrm{G}\end{array}$

$\mathrm{EPC}=(\mathrm{A}-\mathrm{B})-(\mathrm{E}-\mathrm{F})$

$\mathrm{L}=\mathrm{D}-\mathrm{H}$

$\mathrm{PC}=\mathrm{D} / \mathrm{H}$

$\mathrm{SRP}=\mathrm{L} / \mathrm{E}$

Tabel 1. Komponen penyusun policy analysis matrix.

\begin{tabular}{lllll}
\hline \multirow{2}{*}{ Komponen } & \multirow{2}{*}{ Penerimaan } & \multicolumn{2}{c}{ Biaya Fakto Produksi } & \multirow{2}{*}{ Teuntungan } \\
\hline Harga privat & $\mathrm{A}$ & $\mathrm{B}$ & $\mathrm{C}$ & $\mathrm{D}$ \\
Harga sosial & $\mathrm{E}$ & $\mathrm{F}$ & $\mathrm{G}$ & $\mathrm{H}$ \\
Divergensi & $\mathrm{I}=\mathrm{A}-\mathrm{E}$ & $\mathrm{J}=\mathrm{B}-\mathrm{F}$ & $\mathrm{K}=\mathrm{C}-\mathrm{G}$ & $\mathrm{L}=\mathrm{D}-\mathrm{H}$ \\
\hline
\end{tabular}

Sumber : Monke dan Pearson (1995)

Keterangan :

$\mathrm{A}=$ Penerimaan Privat

$\mathrm{B}=$ Biaya Input Trandable Privat

$\mathrm{G}=$ Biaya Input Non Tradable Sosial

$\mathrm{C}=$ Biaya Input Non Tradable Privat

$\mathrm{D}=$ Keuntungan Privat

$\mathrm{E}=$ Penerimaan Sosial

$\mathrm{F}=$ Biaya Input Tradable Sosial

$\mathrm{H}=$ Keuntungan Sosial

$\mathrm{I}=$ Transfer Output

$\mathrm{J}=$ Transfer Input Tradable

$\mathrm{K}=$ Transfer Faktor

$\mathrm{L}=$ Transfer Bersih

3. Hasil dan Pembahasan

\subsection{Analisis Policy Analysis Matrix (PAM)}

Daya saing dan dampak kebijakan pemerintah pada usahatani padi sawah di Kecamatan Biboki Moenleu Kabupaten Timor Tengah Utara dapat diketahui dengan terlebih dahulu melakukan analisis usahatani, yaitu dengan melihat harga input produksi dan biaya produksi usahatani padi sawah di Kecamatan Biboki Moenleu Kabupaten Timor Tengah Utara. Kemudian dilakukan uji daya saing usahatani padi sawah di Kecamatan Biboki Moenleu Kabupaten Timor Tengah Utara dengan menggunakan metode Policy Analysis Matrix (PAM), dapat dilihat pada Tabel 2 dan Tabel 3.

Tabel 2. Komponen penyusun Policy Analysis Matrix

\begin{tabular}{|c|c|c|c|c|c|}
\hline \multirow[b]{2}{*}{ Komponen } & \multirow{2}{*}{$\begin{array}{c}\text { Penerimaan } \\
\text { Output }\end{array}$} & \multicolumn{2}{|c|}{ Biaya Faktor Produksi } & \multirow[b]{2}{*}{ Total Biaya } & \multirow[b]{2}{*}{ Keuntungan } \\
\hline & & $\begin{array}{c}\text { Input } \\
\text { Tradable }\end{array}$ & Non-tradable & & \\
\hline & (A) & (B) & (C) & & (D) \\
\hline Harga privat & 1.114 .790 .000 & $\begin{array}{c}32.700 .654 \\
\text { (F) }\end{array}$ & $\begin{array}{c}211.820 .066 \\
(\mathrm{G})\end{array}$ & 244.520 .720 & $\begin{array}{c}870.250 .280 \\
(\mathrm{H})\end{array}$ \\
\hline Harga sosial & $\begin{array}{c}980.850 .500 \\
(I=A-E)\end{array}$ & $\begin{array}{l}37.735 .688 \\
(J=B-F)\end{array}$ & $\begin{array}{l}131.346 .566 \\
(\mathrm{~K}=\mathrm{C}-\mathrm{G})\end{array}$ & 169.082 .254 & $\begin{array}{l}811.768 .246 \\
(L=D-H)\end{array}$ \\
\hline Divergensi & 133.939 .500 & -5.035 .034 & 80.473 .500 & 75.438 .466 & 58.501 .034 \\
\hline
\end{tabular}

Dari tabulasi Policy Analysis Matrix diperoleh hasil sebagai berikut:

Tabel 3. Indikator Analisis Matrix

A. Analisis Keuntungan

Private Provitability (Keuntungan Privat) $\mathrm{D}=\mathrm{A}-(\mathrm{B}+\mathrm{C})$

Rp.870.269.280

Social Provitability (Keuntungan Sosial) $\mathrm{H}=\mathrm{E}-(\mathrm{F}+\mathrm{G})$

Rp.811.768.246

Efisiensi Finansial dan Efisiensi Ekonomi

Private Cost Ratio (PCR) $\mathrm{PCR}=\mathrm{C} /(\mathrm{A}-\mathrm{B})$

Domestic Resource Cost Ratio (DRCR) DRCR = G/ (E-F) 0,13

\section{Dampak Kebijakan Pemerintah}

1. Kebijakan Output, terdiri dari :

Transfer Output I = A-E

Nominal Protection Coefficient on Output $\mathrm{NPCO}=\mathrm{A} / \mathrm{E}$

2. Kebijakan Input, terdiri dari :

Transfer Input $\quad \mathrm{J}=\mathrm{B}-\mathrm{F}$

Nominal Protection Coefficient on Input $\mathrm{NPCI}=\mathrm{B} / \mathrm{F}$

$\mathrm{K}=\mathrm{C}-\mathrm{G}$

Rp.133.939.500

Rp.1,136554449

Transfer Faktor

3. Kebijakan Input-Output, terdiri dari

Efective Protection Coefficient

Net Transfer

Profitability Coeffisien

$\mathrm{EPC}=(\mathrm{A}-\mathrm{B})-(\mathrm{E}-\mathrm{F})$

Rp. -5.035 .034$

0,86

Rp.80.473.500

Subsidy Ratio to Producer

$\mathrm{L}=\mathrm{D}-\mathrm{H}$

$\mathrm{PC}=\mathrm{D} / \mathrm{H}$

$\mathrm{SRP}=\mathrm{L} / \mathrm{E}$

Rp.138.974.534

Rp.58.501.034

1,07

0,05

\subsection{Analisis Daya Saing}

Daya saing dapat dilihat dari hasil analisis keuntungan dan analisis efisiensi finansial dan efisiensi ekonomi. Dari hasil perhitungan, usahatani padi sawah di Kecamatan Biboki Moenleu, Kabupaten Timor Tengah Utara layak untuk diteruskan dan memiliki keunggulan komparatif dan keunggulan kompetitif dan memilki daya saing serta sudah efisien baik secara ekonomi maupun secara finansial selaras dengan penelitian Septiadi dan Joka (2019). Hal ini dilihat dari keuntungan privat dalam usahatani padi sawah sebesar Rp 870.269.280,- nilai keuntungan tersebut lebih besar dari nol, maka dapat disimpulkan usahatani tersebut layak untuk diteruskan dan memiliki nilai daya saing.dengan kata lain ketika produksi normal dan harga gabah sebesar Rp.
4.000,- atau beras sebesar Rp. 10.000,- dapat menutup biaya produksi, serupa dengan penelitian Hakim (2014) dan Joka (2019).

Selain itu juga dilihat dari nilai keuntungan sosial yang merupakan indikator efisiensi sosial dari komoditas pada kondisi tidak ada penerapan kebijakan, menghasilkan sebesar Rp 811.768.246, nilai keuntungan sosial lebih besar dari nol, maka dapat disimpulkan usahatani tersebut telah berjalan efisien dan memiliki keunggulan komparatif sehingga layak untuk diteruskan. Berdasarkan analisis keuntungan privat dan keuntungan social, diperoleh nilai keuntungan social yang lebih rendah dari nilai keuntungan privat $(\mathrm{SP}<\mathrm{PP})$. Fenomena tersebut disebabkan karena adanya perbedaan antara harga output yang diterima petani untuk gabah sebesar Rp. 4.000,-/kg, beras sebesar Rp. $10.000,-/ \mathrm{kg}$,lebih tinggi dari harga sosialnya yaitu untuk gabah Rp. 3.000,-/kg dan untuk beras Rp. $9.500,-/ \mathrm{kg}$.

Pada analisis efisiensi finansial dan efisiensi ekonomi diperoleh nilai Private Cost Ratio (PCR) sebesar 0,19. Nilai PCR yang diperoleh lebih kecil dari satu, maka dapat disimpulkan usahatani tersebut memiliki keunggulan kompetitif dan mampu membiayai faktor domestiknya pada harga privat. Selain itu pada analisis efisiensi finansial dan efisiensi ekonomi juga diperoleh nilai Domestic Resource Cost Ratio (DRCR) sebesar 0,13. Nilai DRCR tersebut lebih kecil dari satu, maka dapat disimpulkan usahatani tersebut memilki keunggulan komparatif dan mampu membiayai faktor domestiknya pada harga sosial, serta memiliki daya saing ( Van der Eng, 2004; Kariyasa ,2017); dan didukung penelitian Haryanto et al., (2018) yang mengukur daya saing jagung pada lahan marginal, karena pada umumnya lahan pertanian di Provinsi NTT terkhusus di Kecamatan Boboki Moenleu tergolong semi ringkai dengan curah hujan tahunan berkisar 1000 - 1200 mm (Benu dan Mudita, 2013).

\subsection{Kebijakan Pemerintah}

Kebijakan pemerintah juga berdampak nyata pada pendapatan petani padi sawah di Kecamatan Biboki Moenleu Kabupaten Timor Tengah Utara. Hal ini dilihat dari pendapatan petani pada harga privat, yaitu pada saat petani menggunakan input yang sudah disubsidi oleh pemerintah, maka penerimaan petani adalah sebesar Rp Rp 870.269.280. Sedangkan pada harga sosial keuntungan usahatani padi sawah diperoleh sebesar Rp 811.768.246. Maka dapat disimpulkan bahwa keuntungan yang diperoleh petani lebih tinggi pada saat adanya kebijakan. Untuk lebih jelasnya hal ini dilihat dari hasil kebijakan output, kebijakan input dan kebijakan input-output. Pada kebijakan output diperoleh nilai output transfer sebesar Rp. 133.939.500. Nilai output transfer lebih besar dari nol, maka dapat disimpulkan petani menerima insentif dari konsumen dan dalam hal ini konsumen dirugikan atau produsen menerima harga jual yang lebih tinggi dari harga sosialnya, sehingga konsumen dirugikan pada harga privat. Selain itu pada kebijakan output diperoleh nilai Nominal Protection Coefficient on Tradable Output (NPCO) sebesar 1,13. Nilai NPCO lebih besar dari satu, maka dapat disimpulkan adanya proteksi pemerintah terhadap output yaitu beras.

Pada kebijakan input nilai input transfer adalah sebesar Rp -5.035.034 Nilai input transfer lebih kecil dari nol, maka terdapat subsidi pemerintah pada input tradable, sehingga petani tidak membayar penuh biaya sosial yang seharusnya dibayarkan. Selain itu juga pada kebijakan input nilai Nominal Protection Coefficient on Tradable Input (NPCI) sebesar 0,86. Nilai NPCI lebih kecil dari satu, maka dapat disimpulkan adanya kebijakan yang bersifat protektif terhadap input karena ada kebijakan subsidi input tradable. Pada kebijakan input nilai factor transfer sebesar Rp 80.473.500. Nilai faktor transfer lebih besar dari nol, maka dapat disimpulkan terdapat transfer dari petani kepada produsen input non tradabel. Pada kebijakan input-output diperoleh nilai Effective Protection Coefficient (EPC) sebesar 138.974.534. Nilai EPC > 1, maka kebijakan pemerintah masih bersifat protektif. Selain itu Pada kebijakan input output diperoleh nilai Net Transfer (L) sebesar Rp 58.501.034. Nilai $\mathrm{L}>0$, maka dapat disimpulkan terdapat tambahan surplus produsen oleh kebijakan pemerintah yang diterapkan pada input-output. Pada kebijakan input-output diperoleh nilai Profitability Coeffisiens (PC) sebesar 1,07. Nilai $\mathrm{PC}>1$, maka keseluruhan kebijakan pemerintah memberikan insentif kepada petani. Pada kebijakan input-output diperoleh nilai Subsidy Ratio of Producer (SRP) sebesar 0,05. Nilai SRP positif, maka kebijakan pemerintah selama ini (Subsidi pupuk) menyebabkan petani padi sawah mengeluarkan biaya yang lebih kecil dari biaya sosialnya serupa dengan hasil penelitian Haryanto et al.,(2018). Dari hasil penelitian , maka hipotesis kedua diterima yang menyatakan kebijakan pemerintah pada harga input-output berdampak nyata terhadap pendapatan usahatani padi sawah di Kecamatan Biboki Moenleu, Kabupaten Timor Tengah Utara.

\section{Simpulan}

Usahatani padi sawah di Kecamatan Biboki Moenleu, Kabupaten Timor Tengah Utara memilki keunggulan kompetitif nilai Private Cost Ratio (PCR) sebesar 0,19 dan keunggulan komparatif nilai Domestic Resource Cost Ratio (DRCR) sebesar 0,13 sehingga usahatani padi sawah layak untuk diteruskan.

Kebijakan pemerintah pada harga input-output pada usahatani padi sawah di Kecamatan Biboki Moenleu, Kabupaten Timor Tengah Utara berdampak nyata terhadap pendapatan petani padi sawah pada harga privat dengan nilai Nominal Protection Coefficient on Tradable Output (NPCO) sebesar 1,13 dan nilai Subsidy Ratio of Producer (SRP) sebesar 0,05. 
Pustaka

Badan Pusat Statistik Kabupaten Timor Tengah Utara. 2018. Timor Tengah Utara dalam Angka 2018. Kefamenanu.

Benu, F. L., \& Mudita, I. W. 2013. Revisitasi lahan kering: diskusi ringan seputar lahan kering dan pertanian lahan kering. JP II Publishing House.

Hakim, A. 2014. Daya Saing Usahatani Padi Sawah dengan Sistem Pengelolaan Tanaman Terpadu (PTT) di Provinsi Lampung. Tesis: Program Pascasarjana Agribisnis, Fakultas Pertanian, Universitas Lampung.

Haryanto, L. I., Masyhuri, M., \& Irham, I. 2018. The Policy Analysis Matrix in Measuring Competitiveness of Maize Farming System in Marginal Areas. Agro Ekonomi.

Haryono D, Soetrino, Rudi Hartadi, Joni Murti Mulyo Aji, 2011. Analisis Daya Saing dan Dampak Kebijakan Pemerintah terhadap Produksi Kakao di Jawa Timur. Jurnal Sosial Ekonomi Pertanian Vol. 5 (2): 72 - 82.

Joka, U., Anggraeni, L., \& Fariyanti, A. 2019. Impact of PUAP Programs against Rice Farmer's Income in Kupang District of East Nusa Tenggara Province. AGRIMOR, 4(1), 13-15.

Kariyasa, K. 2017. Dampak tarif impor dan kinerja kebijakan harga dasar serta implikasinya terhadap daya saing beras Indonesia di pasar dunia. Analisis Kebijakan Pertanian, 1(4), 315-330.

Monke, E.A. dan S.R. Pearson. 1995. The Policy Analysis Matrix for Agricultural Development. Rev. Edition. Cornell University Press. Ithaca and London.

Pearson S., 2003. Modul of Training of Policy Analysis Matrix in CASERBogor. Stanford: Stanford University.

Roidah, I. S. 2015. Analisis pendapatan usahatani padi musim hujan dan musim kemarau (studi kasus di Desa Sepatan Kecamatan Gondang Kabupaten Tulungagung). J. Agribisnis. 11 (13) : 45-55.

Rum, M.. 2010. Analisis Usahatani dan Kebijakan Pemerintah Terkait Komoditas Cabai besar Di Kabupaten Malang Dengan Menggunakan Policy Analysis Matrix. Jurnal Agribisnis Fakultas Pertanian Universitas Trunojoyo Vol.7 (2): 138 - 143

Septiadi, D., \& Joka, U. 2019. Analisis Respon dan Faktor-Faktor yang Mempengaruhi Permintaan Beras Indonesia. AGRIMOR, 4(3), 42-44.

Umar, H. (2000). Riset Pemasaran dan Perilaku Konsumen. Jakarta: PT. Bumi Aksara.

Van, Der Eng P. 2004. Productivity and Comparative advantage in Rice Agriculture in South-east Asia Since 1870. Asian Economic Journal, Vol. 18 (4): $345-370$ 